\title{
Characteristics of US Travelers to Zika Virus-Affected Countries in the Americas, March 2015-October 2016
}

\author{
Sara Lammert, Allison Taylor Walker, \\ Stefanie Erskine, Sowmya R. Rao, \\ Douglas H. Esposito, Edward T. Ryan, \\ Gregory K. Robbins, Regina C. LaRocque
}

Zika virus has recently been introduced to the Americas and is spreading rapidly. We evaluated the characteristics of US travelers to Zika virus-affected countries who were seen at Global TravEpiNet sites during March 2015-October 2016. Nearly three quarters of travelers were men or women of reproductive age.

$\mathrm{I}_{\mathrm{t}}^{\mathrm{n}}$ n 2014, a total of 30.8 million US residents traveled internationally, and $39 \%$ of trips were to the Caribbean, Central America, and South America (the Americas) (1). Travelers to this region are at risk for mosquitoborne illnesses, including Zika virus infection (2). As of November 1, 2016, a total of 49 countries and territories in the Americas have reported Zika virus transmission (3).

Zika virus spreads primarily through mosquito bites and sexual contact $(2,4,5)$ and is of particular concern to persons of reproductive age because Zika virus infection in pregnancy can cause microcephaly and brain defects $(6,7)$. We describe the demographics of US travelers to Zika virus-affected countries in the Americas, with a focus on persons of reproductive age.

\section{The Study}

Global TravEpiNet (GTEN), supported by the Centers for Disease Control and Prevention (CDC), is a consortium of US clinical practices providing pretravel healthcare to international travelers. GTEN sites include academic practices, healthcare consortia, health maintenance organizations,

Author affiliations: Massachusetts General Hospital Travelers' Advice and Immunization Center, Boston, Massachusetts, USA (S. Lammert, E.T. Ryan, G.K. Robbins, R.C. LaRocque); Centers for Disease Control and Prevention, Atlanta, Georgia, USA (A. Taylor Walker, S. Erskine, D.H. Esposito); Boston University Medical Center Department of Surgery, Boston (S.R. Rao); Massachusetts General Hospital Biostatistics Center, Boston (S.R. Rao); Harvard Medical School, Boston (E.T. Ryan, G.K. Robbins, R.C. LaRocque)

DOI: http://dx.doi.org/10.3201/eid2302.161292 pharmacy-based clinics, private practices, and public health clinics (8). We collected data on persons seen for pretravel consultation during March-October 2016 at 20 participating clinics (8).

We evaluated the destinations, purpose of travel, accommodations, departure month, time to departure, length of travel, and age for all travelers to Zika virus-affected countries in the Americas. We defined a man of reproductive age as being $\geq 15$ years of age and a woman of reproductive age as being 15-44 years of age (9). Among women of reproductive age, we evaluated the frequency of pregnancy, breastfeeding, possible pregnancy in the next 3 months, and use of prescription birth control.

We considered all countries and territories with autochthonous Zika virus transmission as reported by CDC as of November 1, 2016: Anguilla, Antigua and Barbuda, Argentina, Aruba, the Bahamas, Barbados, Belize, Bolivia, Brazil, British Virgin Islands, Cayman Islands, Colombia, Costa Rica, Cuba, Dominican Republic, Ecuador, El Salvador, French Guiana, Grenada, Guadeloupe, Guatemala, Guyana, Haiti, Honduras, amaica, Martinique, Mexico, Netherlands Antilles, Nicaragua, Panama, Paraguay, Peru, Puerto Rico, Saint Kitts and Nevis, Saint Lucia, Saint Vincent and the Grenadines, Suriname, Trinidad and Tobago, Turks and Caicos, US Virgin Islands, and Venezuela (3).

A total of 22,736 travelers were seen for a pretravel consultation during March 2015-October 2016. Of these, $6,440(28 \%)$ planned trips to $\geq 1$ Zika virus-affected country in the Americas. Peru was the most common Zika virus-affected destination (accounting for 25\% of all travelers to Zika virus-affected countries), followed by Brazil $(12 \%)$. Of the 6,440 travelers to Zika virus-affected countries, 4,819 (75\%) were persons of reproductive age.

More than half $(59 \%)$ of travelers to Zika virus-affected countries were women; nearly two thirds $(63 \%)$ of these women were of reproductive age (Table 1). Overall, the most common reason for travel was leisure (59\%). More than one quarter $(26 \%)$ of women of reproductive age were traveling for missionary work or nonmedical service work, and $15 \%$ were traveling for research or education. Only $1 \%$ of women of reproductive age were visiting friends and relatives (hereafter referred to as VFR travelers).

Less than $1 \%$ of women of reproductive age traveling to Zika virus-affected countries reported being pregnant 
Table 1. Demographic characteristics of travelers to Zika virus-affected countries in the Americas, February 2015-October 2016*

\begin{tabular}{|c|c|c|c|}
\hline Characteristic & All travelers, $\mathrm{N}=6,440$ & $\begin{array}{l}\text { Women of reproductive age, } \\
\qquad \mathrm{n}=2,373\end{array}$ & $\begin{array}{c}\text { Men of reproductive age, } \\
n=2,446\end{array}$ \\
\hline \multicolumn{4}{|l|}{ Sex } \\
\hline Female & $3,783(59)$ & $2,373(100)$ & 0 \\
\hline Male & $2,657(41)$ & 0 & $2,446(100)$ \\
\hline Median age (IQR), y & $32(22-51)$ & $26(20-32)$ & $36(25-54)$ \\
\hline \multicolumn{4}{|l|}{ Traveler type } \\
\hline Leisure traveler & $3,816(59)$ & 1,209 (51) & $1,483(61)$ \\
\hline Business traveler & $696(11)$ & $211(9)$ & $357(15)$ \\
\hline Visiting friends and relatives & $110(2)$ & $29(1)$ & $30(1)$ \\
\hline Medical care, providing or receiving & $430(7)$ & $242(10)$ & $135(6)$ \\
\hline Research or education & $714(11)$ & $366(15)$ & 237 (10) \\
\hline Mission or nonmedical service & $1,288(20)$ & $622(26)$ & 439 (18) \\
\hline Adventure & $600(9)$ & $254(11)$ & $231(9)$ \\
\hline \multicolumn{4}{|l|}{ Destination type } \\
\hline Urban only & $1,280(20)$ & 456 (19) & 497 (20) \\
\hline Rural only & $937(15)$ & $332(14)$ & $359(15)$ \\
\hline Both urban and rural & $4,223(66)$ & $1,585(67)$ & $1,590(65)$ \\
\hline \multicolumn{4}{|l|}{ Accommodations $\dagger$} \\
\hline Camping & $645(10)$ & $295(12)$ & $262(11)$ \\
\hline Hostel or dormitory & $1,382(21)$ & $662(28)$ & $519(21)$ \\
\hline Home stay, relatives & $362(6)$ & $107(5)$ & $110(5)$ \\
\hline Home stay, nonrelatives & $1,021(16)$ & $475(20)$ & $366(15)$ \\
\hline Hotel & $4,378(68)$ & $1,516(64)$ & $1,683(69)$ \\
\hline Cruise & $427(7)$ & $68(3)$ & $177(7)$ \\
\hline Other & $953(15)$ & $336(14)$ & $364(15)$ \\
\hline Country of birth, United States & $5,704(89)$ & $2,106(89)$ & $2,147(88)$ \\
\hline \multicolumn{4}{|l|}{ Departure months } \\
\hline Mar-Jun 2015 & $1,050(16)$ & $416(18)$ & $380(16)$ \\
\hline Jul-Oct 2015 & $1,110(17)$ & $389(16)$ & $441(18)$ \\
\hline Nov 2015-Feb 2016 & $1,278(20)$ & $428(18)$ & $490(20)$ \\
\hline Mar-Jun 2016 & $1,587(25)$ & $644(27)$ & $552(23)$ \\
\hline Jul-Oct 2016 & $1,177(18)$ & $423(18)$ & $489(20)$ \\
\hline After Nov 1, 2016 & $238(4)$ & $73(3)$ & $94(4)$ \\
\hline Median time to departure (IQR), $d$ & $22(10-40)$ & $21(10-39)$ & $21(10-39)$ \\
\hline Median length of travel (IQR), d $\ddagger$ & $10(7-15)$ & $10(7-15)$ & $10(7-16)$ \\
\hline Median no. of destination countries (IQR) & $1(1-1)$ & $1(1-1)$ & $1(1-1)$ \\
\hline $\begin{array}{l}\text { *Values are no. (\%) travelers except as indicatec } \\
\text { †Travelers could choose }>1 \text { response. } \\
\ddagger \text { Includes travel up to } 2,000 \mathrm{~d} \text {. }\end{array}$ & adotic & se 15-44 y, men of $r$ & ductive age as those $\geq 15 \mathrm{y}$ \\
\hline
\end{tabular}

$(\mathrm{n}=7)$ or breastfeeding $(\mathrm{n}=9)$ at the pretravel consultation (Table 2). Overall, 42 women $(2 \%)$ reported they were planning pregnancy in the next 3 months; nearly $5 \%$ of women ages 30-39 years were planning pregnancy. Approximately one third of women (34\%) reported using prescription birth control; the highest rate of prescription birth control use (44\%) was among women 20-29 years of age.

\section{Conclusions}

Zika virus transmission has increased in the Americas. Providing pretravel counseling on mosquito bite prevention and risk for sexual transmission of Zika virus and recommending that pregnant women not travel to areas with Zika virus transmission are public health priorities. We describe the characteristics of US travelers seeking health advice before travel to Zika virus-affected countries in the Americas. Our findings suggest areas for intervention.

First, we found that three quarters of travelers seen at GTEN sites before visiting countries with Zika virus transmission in the Americas were of reproductive age. Nearly two thirds of women traveling to Zika virus-affected countries were of reproductive age, and only approximately onethird reported using prescription birth control. Five percent of women ages 30-39 years reported planning pregnancy; not all might have disclosed their plans (nearly half of all pregnancies in the United States are unplanned) (10). Our findings underscore that women of reproductive age, some with immediate plans for pregnancy, are traveling to Zika virus-affected countries in the Americas. CDC has issued Zika virus-related recommendations regarding pregnancy planning for travelers (http://www.cdc.gov/zika/pregnancy/ thinking-about-pregnancy.html). Healthcare providers should stay abreast of these recommendations to counsel travelers to the Americas appropriately.

Second, we found that one quarter of women of reproductive age traveling to Zika virus-affected countries in the Americas were traveling for mission or nonmedical service trips; another $15 \%$ were traveling for research or education. Previous studies show that volunteer travelers are likely to pursue health information but might not adhere to mosquito 
Table 2. Reproductive status of women of reproductive age traveling to Zika virus-affected countries in the Americas, March 2015October $2016^{*}$

\begin{tabular}{|c|c|c|c|c|c|}
\hline \multirow[b]{2}{*}{ Status } & \multicolumn{5}{|c|}{ No. (\%) travelers } \\
\hline & $\begin{array}{c}\text { All women, } \\
N=2,373\end{array}$ & $\begin{array}{c}\text { Ages } 15-19 y \\
n=470\end{array}$ & $\begin{array}{c}\text { Ages } 20-29 y \\
n=1,078\end{array}$ & $\begin{array}{c}\text { Ages } 30-39 y \\
n=588\end{array}$ & $\begin{array}{c}\text { Ages } 40-44 \mathrm{y} \\
\mathrm{n}=237\end{array}$ \\
\hline Pregnant & $7(0.3)$ & 0 & 0 & $6(1.0)$ & $1(0.4)$ \\
\hline Breastfeeding & $9(0.4)$ & 0 & $2(0.2)$ & $7(1.2)$ & 0 \\
\hline Possible pregnancy in next 3 mo & $42(1.8)$ & 0 & $11(1.0)$ & $28(4.8)$ & $3(1.3)$ \\
\hline Using prescription birth control & $803(33.8)$ & $87(18.6)$ & $477(44.3)$ & $194(33.0)$ & $45(19.0)$ \\
\hline
\end{tabular}

avoidance measures $(11,12)$. A survey of volunteers traveling to the Dominican Republic in 2014 demonstrated that only $30 \%$ reapplied mosquito repellant, and $<5 \%$ stayed in accommodations with screens (12). Service organizations might consider educating on mosquito avoidance and distributing mosquito repellant and permethrin-treated clothes for appropriate destinations (13) when their members travel to Zika virus-affected areas. Providing bed nets should be considered for preventing other mosquitoborne diseases.

We previously reported that $\approx 11 \%$ of all travelers seen at GTEN sites were VFR travelers $(8,14)$, and the US Office of Travel and Tourism Industries estimates that 27\% of travelers are VFR travelers (1). Only $1 \%$ of the population in our study were VFR travelers. This finding suggests that VFR travelers to Zika virus-affected countries in the Americas might seek pretravel advice at a lower rate than VFR travelers to other locations ( 8 ) and is noteworthy because VFR travelers are at elevated risk for mosquitoborne illnesses (2).

Our analysis has limitations. Travelers at GTEN sites might not represent all US international travelers, and clinical practice at GTEN sites might differ from other settings where pretravel health care is provided. Also, we did not collect data on contraceptive practices in male travelers; this information would be of interest given the current recommendation for men to use condoms for $\geq 6$ months after their last possible exposure to Zika virus. Last, we did not correlate dates of travel with the time that Zika virus transmission was identified in each country.

In conclusion, our findings show that many persons of reproductive age are traveling to Zika virus-affected countries in the Americas. We observed that VFR travelers represent an unexpectedly small proportion of those seeking health advice before travel to these Zika virusaffected countries; outreach efforts to increase the frequency of pretravel health encounters for these travelers are warranted. Clinicians should provide education on mosquito bite prevention for all travelers to Zika virusaffected countries and should discuss use of condoms or abstinence to reduce the risk for sexual transmission during and after travel. In addition, clinicians should assess reproductive plans, review use of effective birth control, and discuss waiting for conception when returning from areas with Zika virus.

\section{Acknowledgments}

We thank all the members of the Global TravEpiNet Consortium (http://www.globaltravepinet.org).

This work was supported by Centers for Disease Control and Prevention Grants U19CI000514 and U01CK000175.

Ms. Lammert is a research assistant at the Travelers' Advice and Immunization Center at the Massachusetts General Hospital, Boston, and a doctoral student in epidemiology at the University of Minnesota, Minneapolis. Her research interests include travel medicine and infectious diseases.

\section{References}

1. International Trade Administration. Office of Travel and Tourism Industries, US Department of Commerce. Profile of U.S. resident travelers visiting overseas destinations: 2014 outbound [cited 2015 Oct 14]. http://travel.trade.gov/outreachpages/download_ data_table/2014_Outbound_Profile.pdf

2. Centers for Disease Control and Prevention. CDC health information for international travel 2016. New York: Oxford University Press; 2016.

3. Centers for Disease Control and Prevention. All countries and territories with active Zika virus transmission [cited 2016 Nov 1]. http://www.cdc.gov/zika/geo/active-countries.html

4. Oster AM, Russell K, Stryker JE, Friedman A, Kachur RE, Petersen EE, et al. Update: interim guidance for prevention of sexual transmission of Zika virus - United States, 2016. MMWR Morb Mortal Wkly Rep. 2016;65:323-5. http://dx.doi.org/10.15585/mmwr.mm6512e3

5. Hills SL, Russell K, Hennessey M, Williams C, Oster AM, Fischer M, et al. Transmission of Zika virus through sexual contact with travelers to areas of ongoing transmission — continental United States, 2016. MMWR Morb Mortal Wkly Rep. 2016;65:215-6. http://dx.doi.org/10.15585/mmwr.mm6508e2

6. Kleber de Oliveira W, Cortez-Escalante J, De Oliveira WT, do Carmo GM, Henriques CM, Coelho GE, et al. Increase in reported prevalence of microcephaly in infants born to women living in areas with confirmed Zika virus transmission during the first trimester of pregnancy_Brazil, 2015. MMWR Morb Mortal Wkly Rep. 2016;65:242-7. http://dx.doi.org/10.15585/mmwr.mm6509e2

7. Rasmussen SA, Jamieson DJ, Honein MA, Petersen LR. Zika virus and birth defects - reviewing the evidence for causality. N Engl J Med. 2016;374:1981-7. http://dx.doi.org/10.1056/NEJMsr1604338

8. LaRocque RC, Rao SR, Lee J, Ansdell V, Yates JA, Schwartz BS, et al. Global TravEpiNet: a national consortium of clinics providing care to international travelers - analysis of demographic characteristics, travel destinations, and pretravel healthcare of high-risk US international travelers, 2009-2011. Clin Infect Dis. 2012;54:455-62. http://dx.doi.org/10.1093/cid/cir839

9. Oduyebo T, Petersen EE, Rasmussen SA, Mead PS, Meaney-Delman D, Renquist CM, et al. Update: interim guidelines 
for health care providers caring for pregnant women and women of reproductive age with possible Zika virus exposure-United States, 2016. MMWR Morb Mortal Wkly Rep. 2016;65:122-7. http://dx.doi.org/10.15585/ mmwr.mm6505e2

10. Finer LB, Zolna MR. Unintended pregnancy in the United States: incidence and disparities, 2006. Contraception. 2011;84:478-85. http://dx.doi.org/10.1016/j.contraception.2011.07.013

11. LaRocque RC, Rao SR, Tsibris A, Lawton T, Barry MA, Marano N, et al. Pre-travel health advice-seeking behavior among US international travelers departing from Boston Logan International Airport. J Travel Med. 2010;17:387-91. http://dx.doi.org/10.1111/j.1708-8305.2010.00457.x

12. Millman AJ, Esposito DH, Biggs HM, Decenteceo M, Klevos A, Hunsperger E, et al. Chikungunya and dengue virus infections among United States community service volunteers returning from the Dominican Republic, 2014. Am J Trop Med Hyg. 2016;94:1336-41. http://dx.doi.org/10.4269/ajtmh.15-0815

13. García GP, Flores AE, Fernández-Salas I, Saavedra-Rodríguez K, Reyes-Solis G, Lozano-Fuentes $\mathrm{S}$, et al. Recent rapid rise of a permethrin knock down resistance allele in Aedes aegypti in México. PLoS Negl Trop Dis. 2009;3:e531. http://dx.doi.org/ 10.1371/journal.pntd.0000531

14. LaRocque RC, Deshpande BR, Rao SR, Brunette GW, Sotir MJ, Jentes ES, et al. Pre-travel health care of immigrants returning home to visit friends and relatives. Am J Trop Med Hyg. 2013;88:376-80. http://dx.doi.org/10.4269/ajtmh.2012.12-0460

Address for correspondence: Regina C. LaRocque, Gray-Jackson 504, Massachusetts General Hospital, 55 Fruit St, Boston, MA 02114, USA; email: rclarocque@mgh.harvard.edu

\section{May 2016: Vectorborne Diseases}

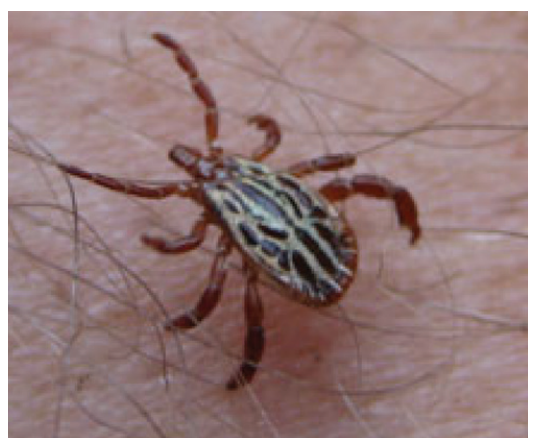

- An Operational Framework for Insecticide Resistance Management Planning

- Plasmodium falciparum K76T pfcrt Gene Mutations and Parasite Population Structure, Haiti, 2006-2009

- Outbreak of Middle East Respiratory Syndrome at Tertiary Care Hospital, Jeddah, Saudi Arabia, 2014

- Differences in Genotype, Clinical Features, and Inflammatory Potential of Borrelia burgdorferi sensu stricto Strains from Europe and and the United States
- Expansion of Shiga ToxinProducing Escherichia coli by Use of Bovine Antibiotic Growth Promoters

- Projecting Month of Birth for At-Risk Infants after Zika Virus Disease Outbreaks

- Genetic Characterization of Archived Bunyaviruses and Their Potential for Emergence in Australia

\section{- Plasmodium falciparum} In Vitro Resistance to Monodesethylamodiaquine, Dakar, Senegal, 2014

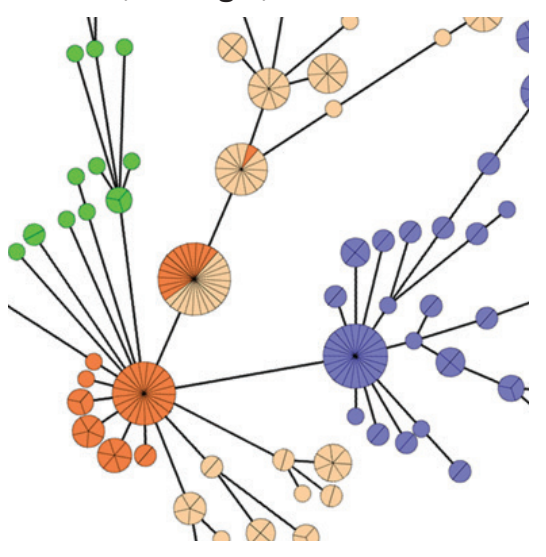

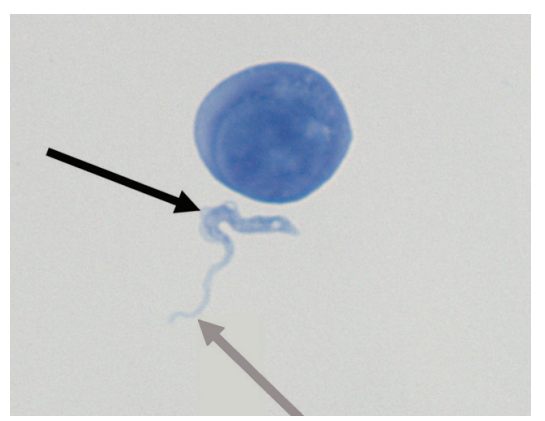

- Astrovirus MLB2, a New Gastroenteric Virus Associated with Meningitis and Disseminated Infection

- Spectrum of Viral Pathogens in Blood of Malaria-Free III Travelers Returning to Canada

- Expanded Geographic Distribution and Clinical Characteristics of Ehrlichia ewingii Infections, United States

- Rickettsia parkeri Rickettsiosis, Arizona, USA

- Acute Human Inkoo and Chatanga Virus Infections, Finland

\section{EMERGING} INFECTIOUS DISEASES http://wwwnc.cdc.gov/eid/articles/ issue/22/05/table-of-contents 